\title{
O Brasil urbano no cinema dos anos 1960: Curitiba melancólica em Lance Maior, de Sylvio Back (1968)
}

\section{Urban Brazil in the 1960's movies: melancholic Curitiba in Lance Maior, by Sylvio Back (1968)}

\section{Introdução}

Em meados da década de 1960 o então jovem cineasta Sylvio Back, residindo em Curitiba, decidiu investir num projeto ousado: um filme de ficção urbana que abordasse criticamente as vicissitudes sociais implicadas no processo de modernização vivenciado pela cidade naquela década. Esboçou as primeiras versões do roteiro a partir de um argumento recorrente, um triângulo amoroso entre jovens de diferentes classes sociais. Mas, ao construir reflexões em torno das relações afetivas, discutiu questões mais amplas vinculadas à modernização.

Rosane Kaminski é professora adjunta de História da Universidade Federal do Paraná (rosanekaminski@ ufpr.br).

Artigo recebido em 17 de dezembro de 2011 e aprovado para publicação em 4 de abril de 2012. 
Aproximou-se, como veremos, de questões prementes em outros filmes de temática urbana produzidos no Brasil naquela década.

Após mais de dois anos e de todo um esforço coletivo na elaboração do roteiro, ${ }^{1}$ filmagens nas cidades de Curitiba e Antonina (PR), edição e sonorização, o filme Lance Maior estreou em outubro de 1968 no Cine São João, em Curitiba, e permaneceu em cartaz por três semanas. Nos meses seguintes, estreou também em Porto Alegre, Rio de Janeiro e São Paulo, marcando o ingresso de Back no meio cinematográfico nacional.

Através de uma estrutura narrativa simples, o filme nos apresenta três jovens que vivem em Curitiba. Apesar do enredo baseado em romance e ambição social, um dos elementos principais do filme é o ambiente da cidade que se moderniza. O presente estudo, portanto, analisa imagens da cidade de Curitiba enquanto "personagem" de Lance Maior, buscando situar o filme dentro de discussões estéticas e ideológicas importantes para a reflexão sobre o Brasil dos anos 1960.

\section{Curitiba-personagem}

Ainda antes da apresentação dos letreiros de abertura do filme, no prelúdio de Lance Maior tomamos conhecimento de três personagens principais: Cristina, Neusa e Mário. Cada um é articulado a um estilo diferente de narração, coerente com suas origens e sua classe econômica. Cristina, moça rica interpretada por Regina Duarte, nos surge sob uma roupagem descontraída e publicitária; Neusa (Irene Stefânia), moça do subúrbio, é vista numa estrutura de fotonovela; Mário (Reginaldo Farias), rapaz oriundo de uma pequena cidade litorânea, é apresentado numa sequência de fotos que sintetizam sua vida desde a infância até o "presente" diegético, quando é um universitário em Curitiba. Enquanto vemos as imagens do seu passado, ouvimos a voz em off do pai do rapaz aconselhando-o a estudar para melhorar de vida. ${ }^{2}$

Logo em seguida, nos é mostrado um quarto personagem fundamental a cidade de Curitiba. Sua apresentação é feita através de quatro planos longos, nos quais a câmera está em constante movimento e passeia pelo ambiente urbano, privilegiando seu espaço físico. Trata-se da abertura oficial do filme, quando, sobre a imagem da cidade, é inserida a ficha técnica.

Aos primeiros acordes de violão, vê-se a imagem de uma praça. A câmera lentamente passeia entre as árvores, e ao fundo percebem-se alguns edifícios modernos. Junto com o título do filme, entra a voz de Marília Pêra entoando uma canção lânguida. Enquanto isso a câmera move-se em suave contra-plongée, eliminando do enquadramento qualquer ser humano. Depois, 
sempre em movimento, volta a situar o eixo de visão a uma altura na qual se nota, à distância, pessoas caminhando na praça e automóveis estacionados. A luz diagonal penetra entre os troncos e projeta longas sombras na calçada, evocando as primeiras horas do dia (ou do entardecer) na atmosfera urbana e promovendo um efeito melancólico condizente com a lentidão da câmera e a canção de fundo. Esse ambiente é o centro da atenção na cena. As pessoas são pequenos figurantes, detalhes quase imperceptíveis, pois a ênfase é para a estrutura urbana: a praça, os edifícios, a rua, a fila de automóveis estacionados.

FIGURA 1: apresentação de Curitiba

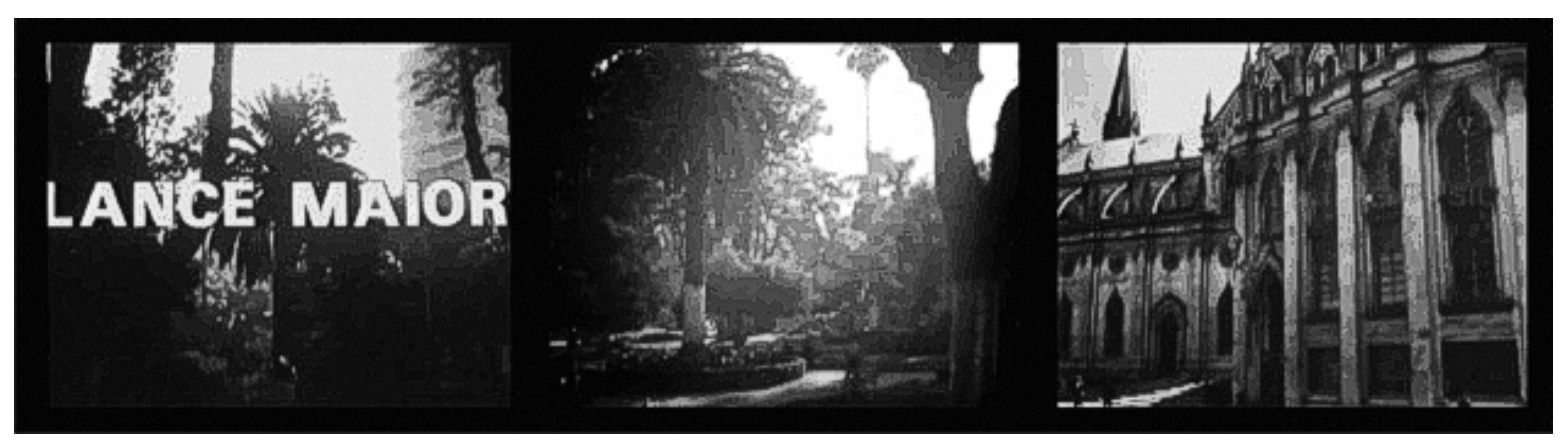

Um corte na imagem nos leva a outra vista. Agora a câmera lenta enquadra a fachada lateral da catedral de Curitiba e segue num travelling horizontal até revelar, por trás da igreja neogótica, os prédios modernos e a movimentação do centro da cidade. $O$ tratamento da imagem lembra trechos de filmes de Antonioni, por demorar-se na descrição do espaço físico urbano, e especialmente porque as pessoas que ali transitam parecem minúsculas, diminuídas pela imponência do cenário arquitetônico. Alem do quê, nesse momento ainda não somos capazes de reconhecer nenhum dos passantes como personagem do filme. Um novo corte nos aproxima de um desses edifícios modernos diante do qual a câmera passa, sempre ao som de voz e violão. Enquanto Marília Pêra entoa os versos finais da música - "E se a gente continua... vai prum beco sem saída... um beco sem saída..." - os prédios vão ficando mais distantes. A música ainda continua por alguns segundos, quando a imagem passa para um plano de conjunto no interior de um trem, fazendo a transição para a próxima sequência.

Todo o trecho descrito opera como uma apresentação da cidade-personagem. Com exceção da catedral - cuja construção data de fins do século XIX -, os demais elementos visuais remetem aos projetos de urbanização que desenha- 
ram Curitiba nos anos 1950 e 60, seja pelo padrão arquitetônico, seja pela organização do trânsito e das praças.

\section{Projetos de modernização urbana em Curitiba}

Ainda que a riqueza do Paraná fosse de origem agrícola e que Curitiba mantivesse um aroma provinciano, era efetiva a expectativa de modernização nas décadas de 1950-60, coerentemente com o que acontecia em outras regióes do país.

Desde o segundo governo de Moyses Lupion (1956-1960), ${ }^{3}$ existia um discurso modernizador alinhado aos pressupostos políticos dominantes no Brasil daqueles anos, ou seja, o Brasil do nacional-desenvolvimentismo do governo de Juscelino Kubitschek. Também foram princípios "desenvolvimentistas" que embasaram a gestão de Ney Braga na prefeitura de Curitiba entre 1954 e 1958 (ocasião em que se dedicou a promover reformas urbanas). Mas somente quando Ney Braga esteve à frente do governo do estado, entre 1961 e 1965, a ideia de modernização se traduziu num projeto para industrializar o Paraná, propondo utilizar recursos agrícolas para o financiamento industrial. ${ }^{4}$

A modernização era colocada, antes de tudo, como um ideal pelas elites dirigentes locais, alinhadas aos planos sustentados pelo governo nacional. Num tal contexto de confiança no desenvolvimento estadual, a esquerda política não tinha proeminência no Paraná. E foi nesse palco marcado pela fragilidade das ideias de esquerda, pelo desejo do moderno mesclado a um ambiente conservador, que Sylvio Back se integrou à cidade, desde que se mudou para Curitiba em 1957.

No curta-metragem As Moradas (1962-1964), produzido por Back em colaboração com outros três jornalistas, sua posição já era de questionamento crítico frente à ideologia do progresso modernizador característico do discurso oficial, tanto do governador Ney Braga quanto do prefeito Ivo Arzua (1962-1966). Este ainda hoje é lembrado pelas transformações urbanas que promoveu em Curitiba, que incluíram obras de saneamento nos bairros e modificações no centro da cidade. ${ }^{5}$

Também em 1962, Back publicou na revista Panorama uma reportagem jornalística intitulada "Curitiba ao avesso". Ali apontava a situação paradoxal que Curitiba experimentava: capital paranaense, considerada exemplo de progresso e de nível de vida alto, era ao mesmo tempo palco de contrastes sociais. A miséria podia ser encontrada tanto nas favelas da periferia quanto nos cortiços do centro da cidade, que ocupavam os espaços vazios em fundos de prédios. Vio- 
lência urbana, greves e desemprego também faziam parte da realidade local. A reportagem ocupava seis páginas da revista, e era abundante em fotografias documentais assinadas por Alcides Machado. É gritante o contraste entre essas fotografias do precário e das imagens de uma Curitiba modernizada, publicadas com mais frequência nas páginas da mesma revista desde o início do governo de Ney Braga. A maioria das matérias eram laudatórias em relação ao progresso, à verticalização da cidade, à abertura de ruas, e nesse contexto a posição de Back surgiu como uma visão crítica da modernização:

61 deixou triste rastro de paradoxos. Mais que o de $60 \mathrm{e}$ anos anteriores. Progresso a olho nu e miséria nas ruas, com o deprimente espetáculo de mendigos, indigentes, crianças, aleijados e doentes abordando os transeuntes. (...) A fome, autêntico lugar-comum; vadiagem, roubos e latrocínios, idem. Salários cedidos sem o mínimo de racionalismo, e à força de pressões políticas, não atendem às carências primárias da grande população. Greves e greves são necessárias, e a cada movimento cresce o número de desempregados, que chegam estupefatos para engrossar o formidável exército dos miseráveis oficiais. (...) E os polos distanciam-se a cada dia. Vive-se cercado de párias e favelas versus privilegiados e moradias de luxo. Curitiba, exemplo nacional de grandiosidade e desenvolvimento, nível de vida alto e estável, adentrou irremediavelmente no rol dos melancólicos palcos do contraste social. De Pasárgada, a Capital do Paraná transformou-se num problema. Invadida sua periferia de favelas e cortiços, homiziando aglomerados urbanos flutuantes, entre 25 a 30 mil infelizes, na maioria oriundos do norte do estado e do país, agora, o centro da cidade capitulou ante o ímpeto da miséria (Back, 1962).

Enfim, enquanto se discutiam os planos urbanísticos da capital, o tema das contradições sociais na cidade seria desenvolvido criticamente por Back na forma cinematográfica, inicialmente em As Moradas e, alguns anos mais tarde, em Lance Maior.

\section{O urbano no cinema dos anos 1960 e em Lance Maior}

Nos anos 1960, a paisagem arquitetônica urbana foi objeto de atenção em obras de diversos cineastas que desejaram relacionar as angústias de seus personagens às pressões advindas com a modernidade: degradação, divisão do tra- 
balho, atomização social, solidão, vazio existencial e questionamento dos valores burgueses. A vida na cidade é tema importante em filmes de Visconti (Rocco e seus irmãos, 1960), Fellini (La Dolce Vita, 1960) e Antonioni (A Noite, 1960), e também de brasileiros como Walter Hugo Khoury (Noite vazia, 1964, e As amorosas, 1968), Cacá Diegues (A grande cidade, 1966) e Luiz Sergio Person (São Paulo $S / A, 1965)$, entre tantos outros.

Destes, o São Paulo S/A, que foi inclusive citado por Back (1967: 24) como um filme brasileiro sério, será tomado, em alguns pontos deste texto, no cotejo das formas usadas por Person e por Back para representar a paisagem da cidade moderna. Outra aproximação é que ambos abordam criticamente a postura da classe média diante do fenômeno da expansão capitalista, que, no caso do Brasil dos anos 1960, implicou uma divisão entre a radicalização política à esquerda ou a adesão ao modelo econômico seguido pelo governo, aproveitando os privilégios da sociedade de consumo (Evers, 1982: 93-94). A segunda opção foi seguida pela maioria dos pequeno-burgueses e assalariados de serviços, sendo que o golpe de 1964 e o governo militar por ele instituído receberam amplo apoio das classes médias. ${ }^{6}$

De acordo com Bernardet (1978: 111), no cinema brasileiro o São Paulo $S / A$ foi "um dos primeiros filmes que colocaram com agudez o problema da classe média (...) no momento da euforia desenvolvimentista pela instalação no estado de São Paulo de indústrias automobilísticas estrangeiras”. Guardadas as especificidades histórico-sociais e econômicas de cada cidade (São Paulo e Curitiba), e as proporções dos efeitos do desenvolvimentismo em cada uma delas, vê-se que a realidade das classes intermediárias numa cidade que se movimenta sob o motor do capitalismo foi também um dos motes centrais de Lance Maior, realizado três anos depois do filme de Person.

Certamente as formas de representação, os recursos expressivos, a verticalidade na abordagem dos temas, são distintos em cada um dos cineastas que trabalharam com a representação do homem asfixiado pelo ambiente urbano. Ao situar Lance Maior entre outros que se debruçaram sobre esse mote nos anos 1960, a intenção é visualizar um quadro de referências fílmicas com as quais Back buscou dialogar, tanto em produções internacionais quanto nacionais, quando formulava sua primeira ficção cinematográfica. Nesse sentido, podem ser enumeradas algumas características presentes em diversos filmes produzidos ao longo da década de 1960 que situam o indivíduo na paisagem urbana: a atmosfera reflexiva e melancólica, a crise ideológica, o olhar sobre a classe média urbana, a ausência de sentimentalismo e a falta de clímax. Tudo isso privilegiando a visualização da urbe em processo de modernização capitalista e as estruturas delineadas pelo poder econômico, enquanto espaço no qual as ações se desenvolvem e se mesclam. 
Nesse quadro, há algo especial a ser notado no caso de Lance Maior: ali os dramas vividos pelos personagens não se "destacam" do cenário no qual transitam. Se no início do filme a exposição dos assuntos parece que se desdobrará num enredo capaz de nos fazer mergulhar em profundidade nas aflições dos personagens, aos poucos se percebe Mário, Neusa e Cristina como pessoas comuns, tão comuns que só os vemos em superfície, achatados no ambiente urbano em que vivem. A falta de profundidade no tratamento psicológico dos personagens nivela-os ao espaço em que são mostrados. Desse modo, o espaço urbano é mais do que cenário, é também personagem.

Se a cidade fosse mostrada somente naquele momento da apresentação dos créditos, poderíamos encará-la apenas como o pano de fundo para o desenvolvimento da história, já que ela divide o foco de interesse com os letreiros e com a música. Entretanto, de modo parecido com o que fez Person em São Paulo $S / A$ - que explora as imagens da capital paulista durante a apresentação dos letreiros e também em outros pontos do filme -, a fotografia curitibana voltará a tomar imponência em diversos momentos da narrativa em Lance Maior, evidenciando-se como aspecto privilegiado pelo cineasta.

Assim como não promove o mergulho psicológico nos integrantes do círculo amoroso, Lance Maior também não direciona sua crítica social a uma situação bem específica que possa ser tomada como figura central. Ao invés disso, Back elabora um painel sobre o qual se justapõem afetos, ambições, angústias e busca de identificação social a partir de valores planificados pela ideologia da modernidade. O anteparo, capaz de unificar e entrelaçar todos esses elementos, é a cidade na qual transitam os personagens que são ao mesmo tempo portadores e personificações de tais anseios e valores. Esse anteparo é exposto como assunto sobre o qual o cineasta centraliza boa parte do trabalho de câmera, conferindo-lhe um aspecto melancólico pela expressão do indivíduo solitário na multidão.

FIGURA 2: Neusa em meio à agitação urbana

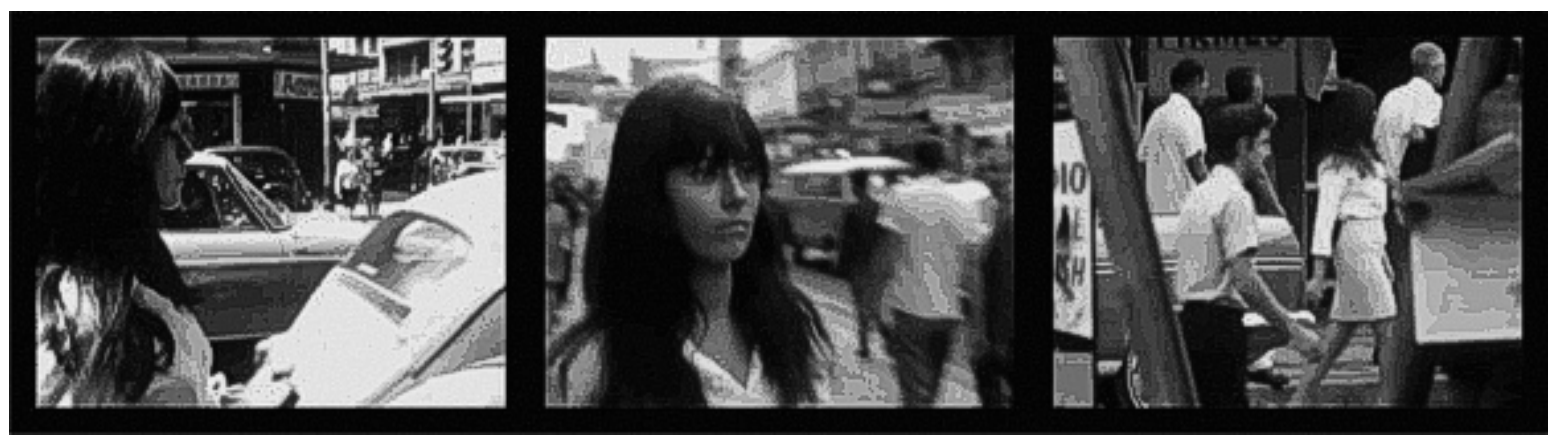


Alguns dos momentos em que o cenário urbano vem à tona como personagem em Lance Maior são aqueles em que Neusa passeia pelo centro da cidade. A câmera assume algum lugar no meio dos transeuntes e focaliza-a andando pela rua. A melodia-tema da personagem ambienta a cena, enquanto ela caminha por entre a agitação urbana. A música é retraída quando entra a voz over da moça, expondo suas memórias ou seus pensamentos. $\mathrm{O}$ assunto é a precariedade que emoldura sua vida, exemplificada no diálogo (over) com as colegas de trabalho sobre a necessidade de remendar as meias de nylon rasgadas, pois o parco salário de balconista não permite comprar novas.

Logo após esse mergulho nos pensamentos da moça, os planos a seguir mostram-na de pontos cada vez mais afastados. Vemo-la do outro lado da rua, e depois mais ao longe, em meio à inquietação do centro da cidade. A música silencia, e então o "assunto" que emerge da cena é a afluência das pessoas, os ruídos citadinos, a movimentação dos carros, a fila do ônibus, as vitrinas, cartazes, letreiros etc. Ou seja, o cenário urbano onde os indivíduos se pulverizam, fundindo sua própria identidade à da multidão. A câmera, num tratamento cinematográfico moderno, mescla-se ao ambiente tornando-se mais um personagem que se movimenta nesse cenário. Para flagrar Neusa de longe, é preciso se desvencilhar de obstáculos visuais, procurá-la por sobre os ombros dos transeuntes, ou pelos espaços entre agrupamentos humanos e automóveis que passam.

Enquanto a câmera nos oferece esse ponto de vista de "dentro" do espaço urbano, dele fazemos parte, ouvimos seu burburinho, percebemos sua dinâmica, seu jogo de simultaneidades, seu ritmo. Estamos lá, seguindo Neusa quando se dirige para a fila de ônibus. Ela é apenas mais um ser anônimo na multidão, e sua interação com as outras pessoas é mínima. Sem pensar, ela recebe automaticamente um panfleto publicitário entregue por um rapaz. Esse pequeno detalhe mostra-a ao mesmo tempo indiferente e suscetível à influência da publicidade, atuando como representação plástica do ser humano massificado, nos termos de Arendt (2003: 250-251): o ser urbano que se caracteriza pela sua solidão a despeito de sua adaptabilidade, pela sua falta de padrões, pela sua capacidade de consumo aliada à inaptidão para julgar, e sobretudo pelo seu egocentrismo.

Mais adiante, depois de cenas centradas no mundo de Mário ou de Cristina, a câmera volta a se ocupar do centro da cidade em cujo desenho Neusa passeia mais uma vez, agora com sua amiga Marga (Isabel Ribeiro). A presença das duas, contudo, é apenas um mote para que se volte a atenção para o "anteparo" que é a urbe na qual elas se diluem e se refletem, na busca de afirmação identitária. Anteparo sobre o qual aparentemente as diferenças sociais se apagam, se planificam, como quando vemos em plongée a movimentação da rua na qual Neusa e Marga são pequenos pontos no cenário, fundindo-se com o conjunto daquilo que nomeamos "cidade" - mas isso não passa de uma ilusão. Ao mesmo tempo 


\section{Rosane Kaminski}

em que o discurso moderno impresso na publicidade, nas fotonovelas, nos panfletos etc., diz que "somos todos iguais", com direitos iguais, a disparidade socioeconômica reforça que cada um só pode se manter em seu próprio espaço.

\section{Classe média urbana e atomização social}

Como indicativos da crise ideológica experimentada pela classe médiaora o desejo de participar de uma camada social que não é a sua, ora a constatação da ausência de projetos próprios -, os personagens humanos em Lance Maior são seres atomizados, transitando como pequenos insetos na imponente e melancólica paisagem urbana. ${ }^{7}$ Em meio à agitação, suas ações se neutralizam, quase desaparecem. Mário surge minúsculo e achatado no espaço vazio do Largo da Ordem; Neusa misturada com a multidão. Isso cria a impressão do indivíduo perdido e comprimido no cenário urbano.

\section{FIGURA 3: Mário no Largo da Ordem}

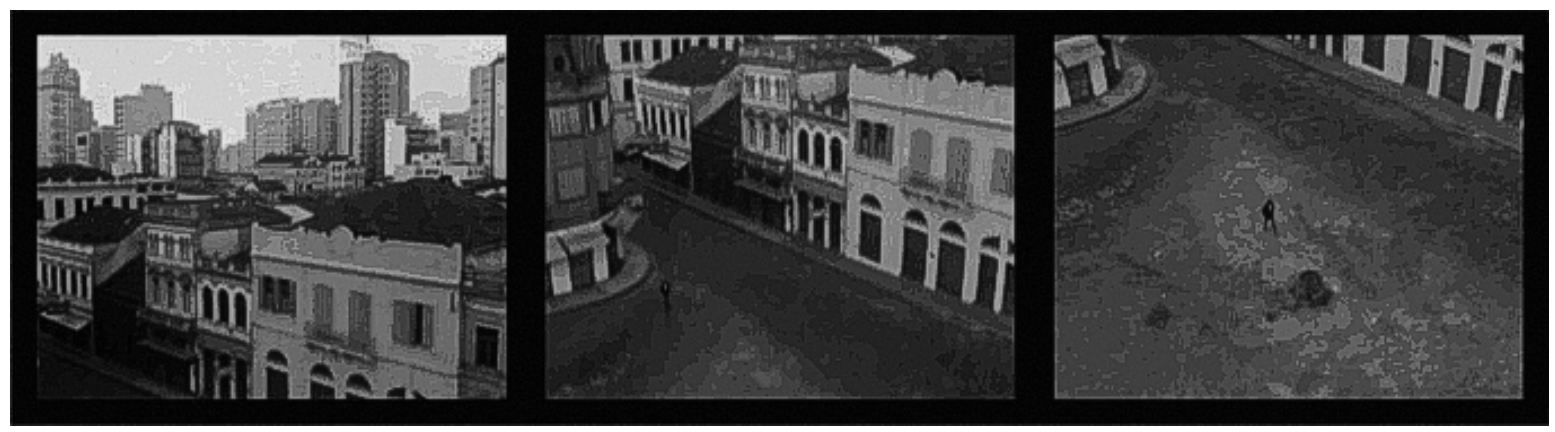

Além das imagens da paisagem citadina, a representação dos espaços de trabalho de Neusa e Mário também conduz à ideia de atomização social, presente de outras maneiras em outros filmes urbanos daquela década, como o já mencionado São Paulo $S / A$.

O local de trabalho de Neusa será visto apenas lá pela metade do filme. Já sabemos que ela é uma balconista de loja, e a vimos entre as funcionárias num vestiário arrumando-se após o expediente. Mas agora o lugar em que ela trabalha é mostrado de um jeito peculiar. A câmera se "esconde" num canto do estabelecimento, e mostra num só enquadramento duas faces da organização urbana: o interior da loja de tecidos e a rua, lá fora. 
FIGURA 4: Vista do interior da loja de tecidos

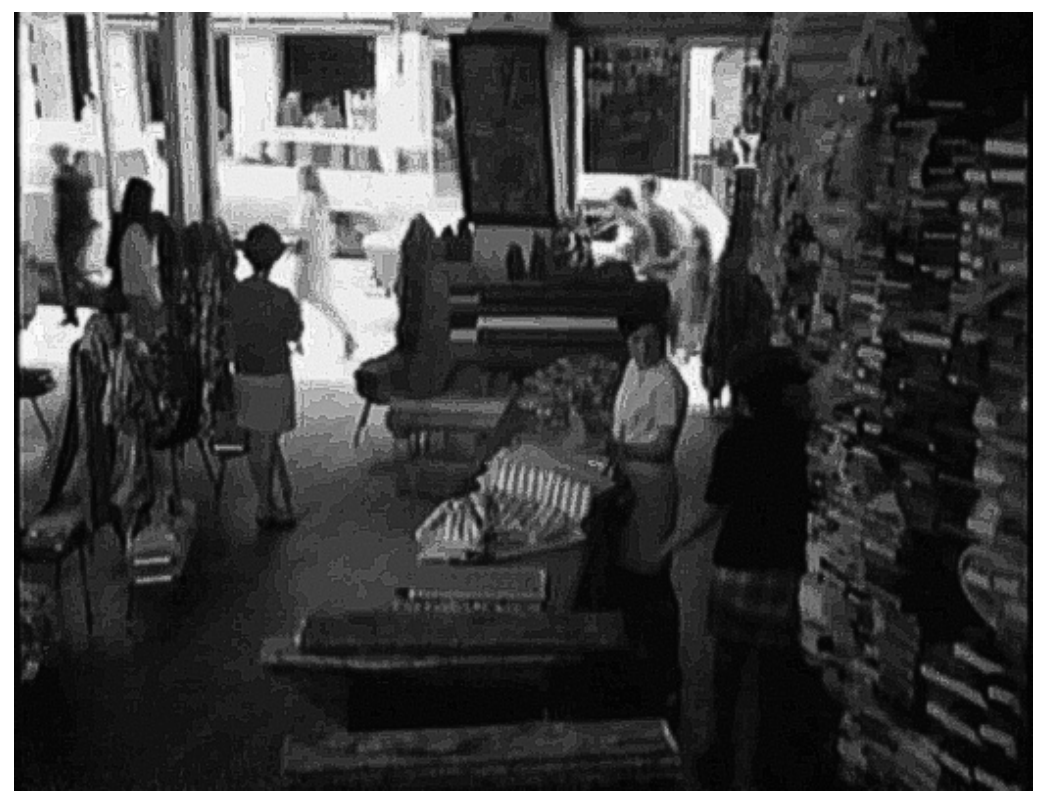

O interior da loja é monótono, sem movimentação. Algumas funcionárias ficam em pé perto da porta esperando que os clientes entrem, estão ali prontas para servi-los. É o caso de Neusa. Outras moças dobram e guardam os tecidos que ficaram sobre os balcões, queixando-se da dor nas pernas, do expediente longo, e comentando o caso da demissão de uma colega. A rua, por sua vez, é movimentada, luminosa, vivaz. As funcionárias que olham os passantes parecem aprisionadas no interior da loja, enquanto o dinamismo da vida na cidade acontece lá fora. A cena sintetiza algo do funcionamento da estrutura econômica de poder da vida moderna. Para participar dessa dinâmica urbana, ainda que em posição subalterna, as moças do subúrbio procuram empregos no comércio do centro da cidade, e exemplificam o que Evers (1982) define como "assalariados não produtivos" em sua classificação das classes médias modernas. ${ }^{8}$ São serviçais, vendem suas horas de trabalho por um salário baixo, mas indispensável, em empregos que não exigem conhecimento especializado, e pelos quais não demonstram nenhum gosto especial. Ao mesmo tempo em que ambicionam participar dos benefícios usufruídos pelas classes mais abastadas, o que garante a sua adesão ao modelo político e econômico, elas não demonstram ter um projeto de vida mais profundo. A impossibilidade de escolha e a ausência de metas próprias provocam sua atomização. 
O caso de Mário não é muito diferente. Para cursar a faculdade de direito precisa manter um emprego no banco. É assalariado e se submete às regras do jogo impostas por seus superiores. Mas quando ensaia o pedido de casamento que pretende fazer ao pai de Cristina, verbaliza suas ambições:

No que eu me formar, já abro escritório. O senhor entende, advogado sempre tem mais chance. No início pode ser apertado, mas pretendo acumular. Acho que só assim a gente consegue alguma segurança, não doutor? É que eu não quero ficar marcando passo na vida, entende? Eu tenho planos...

Seus planos, porém, são apenas a integração num estrato social acima daquele do qual é proveniente. $\mathrm{O}$ trecho sugere que seus objetivos com o estudo não passam de ambição econômica.

Os trabalhos bancário e de balconista consistem, como se sabe, em profissões urbanas e modernas, e as funções exercidas por Mário e Neusa são geralmente ocupadas pela classe média e média-baixa, respectivamente. É uma situação representativa da divisão de trabalho relacionada com a distribuição social do conhecimento que contribui para manter as relações de poder e dominação. Nesse ponto, na representação dos encaixes profissionais, Lance Maior também apresenta semelhanças com São Paulo $S / A$, com a grande diferença que o filme de Person focaliza muito mais os ambientes vinculados à indústria automobilística. Já Lance não mostra Curitiba como cidade industrial, o que ela de fato ainda não era quando o filme foi produzido. ${ }^{9}$

O filme de Back privilegia a divisão do trabalho em profissões urbanas, relacionadas à manutenção das relações de poder e distinção social. No caso do filme $S a \tilde{o}$ Paulo $S / A$, a cidade é mostrada sobretudo sob o aspecto da expansão industrial e publicitária que foi experimentada na capital paulista durante a década de 1950. Inclusive com cenas filmadas em setores de montagem da indústria automobilística e nas fábricas de autopeças que "surgiram em São Paulo da noite pro dia", como diz o personagem Carlos, dentro do "programa de nacionalização dos veículos", que precisava ser acelerado. A comparação entre a imponência e agressividade do processo vivido na capital paulista e o projeto modernizador de Curitiba confere a esta última ares ainda tímidos e provincianos. Apesar dessas diferenças, contudo, os dois filmes têm em comum a representação da falta de projetos dos personagens de classe média que transitam no meio urbano.

Assim, a estratificação social é um dos temas de Lance Maior, exposta no sentido da imobilidade e do "aprisionamento" de cada personagem em seu estrato de origem. Isso é evidente na própria estrutura narrativa circular do filme: 
após algumas voltas e intercâmbios com personagens de outros estratos, os namoros são desfeitos, e cada qual permanece no mesmo lugar. $\mathrm{O}$ foco dessa estrutura aponta para a manutenção social das relações de poder, sobretudo pelo aspecto econômico e pelo consenso quanto à ideologia da igualdade pregada pela publicidade. Gestada e preservada por um jogo de espelhamentos alimentado pela mídia, essa ideologia gera o desejo de ingresso num patamar de consumo reservado a poucos, conforme o funcionamento atroz da teia de aspirações no qual o consumidor é envolvido para garantir o funcionamento da lógica social capitalista (Baudrillard, 1972: 131-147). O centro de Curitiba, por onde Neusa transita, carrega esse discurso. Em algumas passagens, o trabalho de câmera mostra-o com sutileza.

FIGURA 5: Neusa e Marga diante das vitrinas

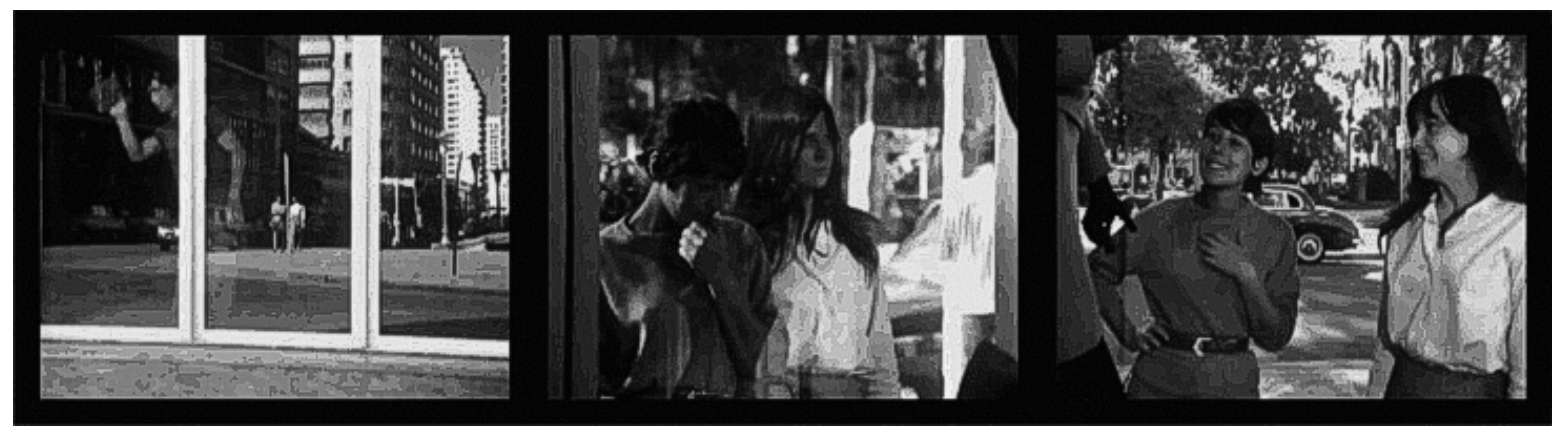

Um exemplo é o longo plano em que uma vitrina espelhada ocupa todo o enquadramento refletindo a movimentação da rua. Uma mulher limpa o vidro pelo lado de dentro da construção, permitindo identificar a cena como reflexo. É um recurso parecido com aquele usado na abertura do filme São Paulo $S / A$ : lá a câmera flagra uma discussão de casal que acontece num apartamento. Não se pode ouvir o que dizem, só se vêem seus gestos, pois a cena é filmada pelo lado de fora de uma vidraça sobre a qual está refletida a paisagem de edifícios da cidade de São Paulo. Vê-se, simultaneamente, o reflexo e a situação que se passa dentro do apartamento. Depois a câmera desliza para o lado mostrando a parede externa do prédio e gira em torno de si, apresentando a vista urbana.

Em Lance Maior, a vidraça espelha a movimentação dos automóveis e ônibus que passam entre os prédios. Em meio aos transeuntes refletidos no vidro pode-se identificar Neusa e Marga. Reconhecemo-las antes pela voz over do que pela imagem. Elas se aproximam cada vez mais da vidraça, até que passam efeti- 
vamente diante da câmera, não mais espelhadas. No plano seguinte a câmera está dentro de uma vitrina, ocupando o lugar dos objetos expostos. Vemos as duas moças paradas diante dela, comentando sobre as mercadorias que se oferecem aos seus olhos desejosos e que lhes são inacessíveis. Continua o jogo de espelhamentos iniciado no plano anterior, mas a vidraça assume agora um papel coercitivo: simboliza a barreira entre o desejar e o possuir, ainda que o discurso da publicidade prometa a todos a possibilidade de consumo.

A exposição de objetos de consumo ao público planificado das ruas, acessíveis aos seus olhos e protegidos de suas mãos pela parede de vidro, sinaliza o funcionamento das relações de poder nesse modelo de vida. $O$ consenso se sustenta por meio do desejo de atingir, de algum modo - seja pelo casamento bem-sucedido, como querem Neusa e Mário, seja pelo estudo, como acredita o pai de Mário -, a condição de classe econômica privilegiada.

Representar esse jogo era, justamente, uma das intenções dos roteiristas. No mesmo dia da estreia de Lance Maior, o jornal O Estado do Paraná publicava seus depoimentos sobre o filme. Back (1968) dizia que pretendia "revelar o povo a ele mesmo, isto é, mostrar-lhe pela prática o quanto é vítima dos meios de conformação ideológica das classes dominantes e que sua libertação nunca se dará em termos de guerra pessoal”. E Volpini (1968) afirmava que:

Com uma estória de amor, quisemos mostrar a impossibilidade do amor numa sociedade de privilégios e profundos desníveis, onde o egoísmo prevalece necessariamente, e tudo vale, então, para a ascensão individual na sociedade, mesmo que só alguns poucos possam entrar nesse lugar. Embora a luta de classes possa ser vislumbrada, em sua forma consequente, preferimos dar ênfase à luta pessoal, apresentando-a criticamente, porque é ainda esta predominante.

Nesse sentido, na cena em que Neusa admira as vitrinas de lojas sonhando com seus produtos de consumo, explicita-se a contradição entre o mundo em que se espelha e aquele a que ela efetivamente pertence. Isso é verbalizado no momento em que a amiga Marga diz, diante da vitrina na qual ambas cobiçam os vestidinhos da moda: "Mas os preços, nossa! Não é pra gente...”, ao que Neusa responde: "Quem sabe?”.

O disparate entre sua realidade social e sua ambição fica mais evidente quando, após cobiçar os produtos nas vitrinas, Neusa toma um ônibus para casa. No trajeto ela mergulha na leitura de uma fotonovela enquanto se vê a paisagem urbana pela janela.

Chegando ao subúrbio, a câmera flagra a pobreza do bairro onde ela mora com sua família: os atalhos pelos terrenos baldios, o pó das ruas sem calça- 
mento, as casinhas simples de madeira em cujos quintais mulheres penduram roupas nos varais enquanto crianças brincam de pés descalços.

FIGURA 6: Bairro de Neusa

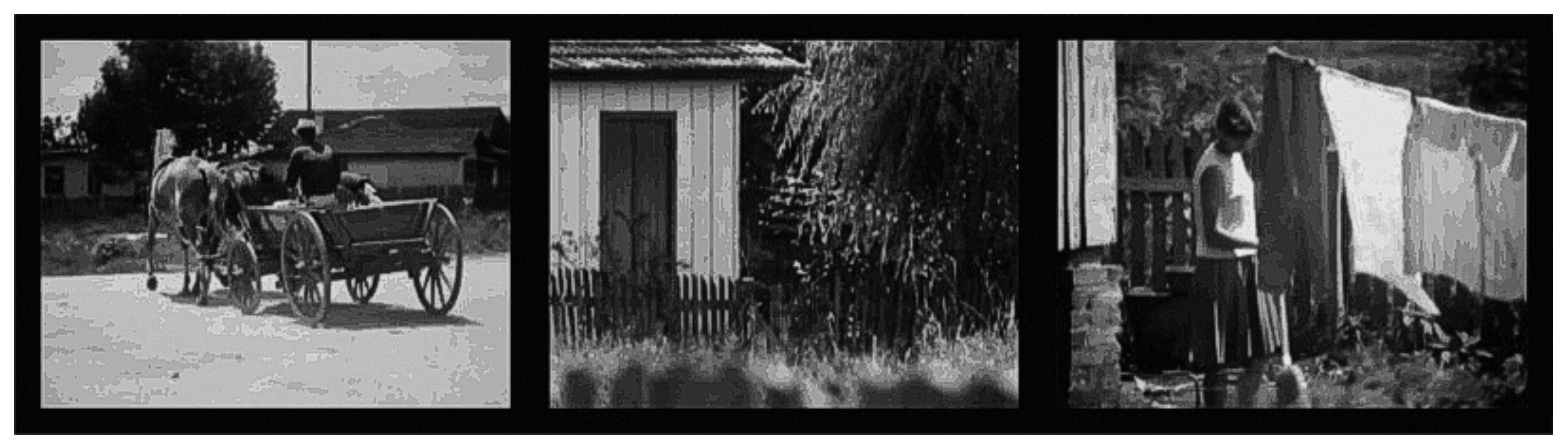

A voz off de Neusa comenta que ela se cansou do "miserê", e que quer mudar de situação. Não se trata, evidentemente, de querer uma modificação da estrutura social, e sim do desejo de mudar seu lugar individual nessa estrutura. Trata-se de uma busca individual e despolitizada, que possibilita a leitura da personagem como esquema da atomização social, naqueles termos arendtianos. Neusa não questiona a desigualdade social como um todo, apenas não admite que não possa participar das vantagens de outras classes. Nesse ponto, se equipara a Mário, assalariado, que vive num quarto de pensão antiga, numa região decadente do centro, onde frequenta casas de prostituição, mas segue sonhando com o casamento com Cristina, que lhe proporcionará uma vida "de rico". Desde que o vemos expressar com desprezo aos amigos num bar que não pensa em casar com "guria de loja", visualiza-se a mesquinhez do seu interesse por Neusa.

\section{Facetas do obsoleto e do moderno}

Logo que conhecemos o subúrbio no qual Neusa mora, fica mais claro que a cidade-personagem também possui várias facetas. Se até aqui as cenas comentadas permitiram construir uma imagem do espaço urbano como painel onde tudo e todos se planificam, há outras, em Lance Maior, que deixam óbvios os contrastes sociais e materiais.

Cristina aparece sempre em cenários nos quais predominam a arquitetura e os monumentos modernos. São espaços de distinção social ou que repre- 
sentam a modernização conservadora da cidade promovida pelas elites locais desde os anos 1950. A personagem aparece com a família ou nas festinhas com amigos em residências ricas, ou então na sede dos cursos de Filosofia e Ciências Humanas da Universidade Federal do Paraná, construída nos anos 1950. Outro espaço significativo é o clube com piscina, já que frequentar tal local era um hábito da elite curitibana nas décadas de 1950-60, quando vários clubes construíram piscinas. ${ }^{10}$

FIGURA 7: Cristina e a amiga Odete na piscina do clube

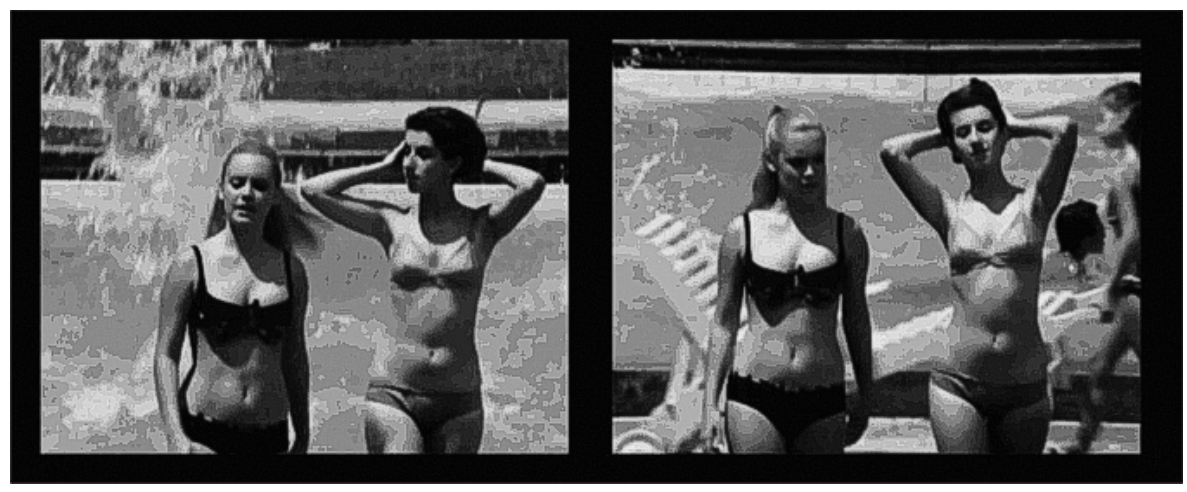

Todos esses espaços se opõem de forma gritante à precariedade no bairro de Neusa, onde não havia sequer água encanada (condição insinuada quando seu pai bombeia água num poço).

Os espaços habitados por Neusa e por Mário são como que os "subterrâneos" da cidade que se moderniza, para usar um termo do próprio Back naquela matéria que publicara em 1962 na revista Panorama. Os subterrâneos e marginálias também se expandiam na Curitiba das propostas de modernização, acompanhando os notáveis índices de crescimento populacional da cidade naquela década.

As facetas contraditórias que participam do mesmo processo de modernização urbana também são evidenciadas na justaposição das cenas em que Mário está sozinho e das em que ele se encontra com Cristina. No quartinho de pensão, ele convive com um varal improvisado, uma mobília desgastada, vidraças forradas com papel ao invés de cortinas, imagens de mulheres nuas e calendários como decoração. Enquanto se queixa de sua situação e da doença venérea que contraiu, repete várias vezes: “Cidade podre, essa!". Nas ruas, transita entre prostitutas, revelando um "submundo" que contrasta com suas ambições e com seu comportamento de bom moço diante de Cristina. 
Quando se encontra com a moça rica, no entanto, adentra no espaço urbano que corresponde a ela: o Country Club ou a recém-inaugurada Praça 29 de Março, imagem do desenvolvimento urbano.

Nessa praça, especialmente, os enquadramentos de câmera compondo três longos planos criam um efeito de sentido interessante: no início, uma vista em perspectiva do espaço arquitetônico - os grandes blocos de concreto, as formas geometrizadas, a calçada com amplo quadriculado. Num dos blocos, vêem-se araucárias estilizadas que fazem parte de um painel elaborado pelo artista Poty Lazzarotto e que constituem o único ornamento da edificação. Quando Mário entra na cena, ao fundo, parece um ser solitário aprisionado num aquário de cimento armado. Logo chega Cristina até ele, e ambos caminham vagarosamente enquanto conversam, vindo para perto da câmera. Os dois planos seguintes fornecem vistas em ângulos diferentes do cenário no qual os dois passeiam, à beira do espelho d'água, com a paisagem dos edifícios urbanos ao longe, no plano de fundo. Estão isolados do restante da cidade, afastados da multidão, mas ainda fazem parte dela. Essa praça de concreto, projetada por Jaime Lerner e situada no bairro das Mercês, numa região nobre de Curitiba, era um monumento recentemente edificado, como parte da primeira fase do plano urbanístico iniciado na gestão de Ivo Arzua. A inauguração da praça acontecera em novembro de 1966, pouco mais de um ano antes de Back filmar Lance Maior. Os segundos finais da sequência mostram, em plongée, o casal de mãos dadas, andando sobre o amplo espaço quadriculado formado pela calçada. A câmera se afasta cada vez mais, ampliando o enquadramento, ao som da mesma música que abre e que fecha o filme. Somente nesse momento é possível ver umas poucas pessoas na praça, distinguindo-se este local das ruas centrais da cidade justamente pela ausência de transeuntes. É quase um "Olimpo", do qual se vê, ao longe e numa região mais baixa, o centro.

FIGURA 8: Mário e Cristina na praça 29 de Março

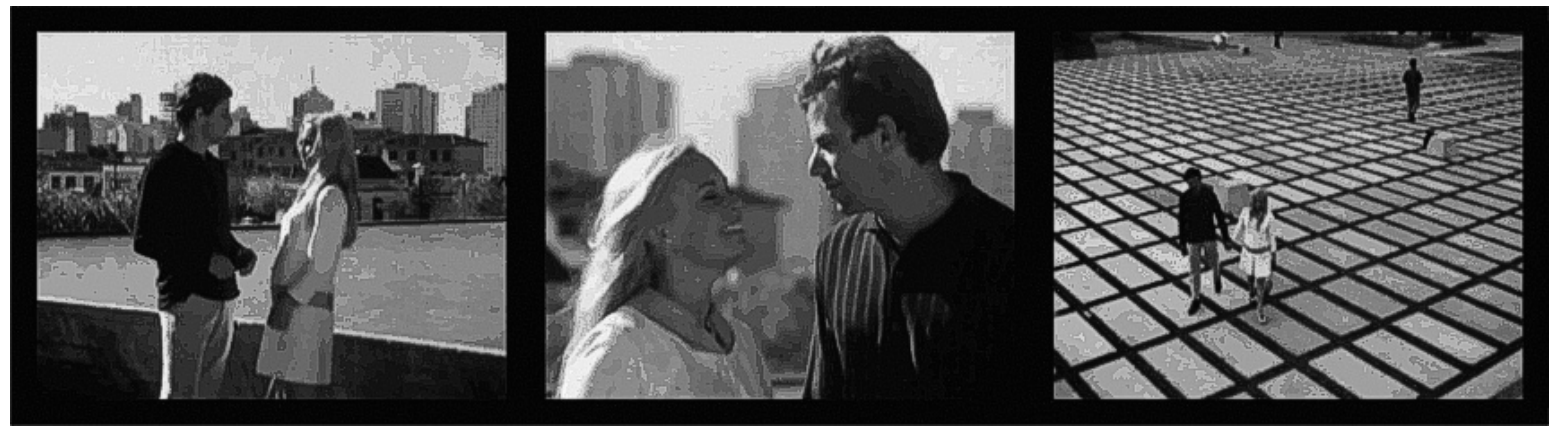


Em São Paulo $S / A$ existe um momento com um sentido parecido, quando Carlos e Hilda visitam uma exposição de artes no espaço projetado por Oscar Niemeyer, no Parque Ibirapuera (inaugurado em 1954, no IV Centenário de São Paulo), lugar que representa, por excelência, o gosto artístico e o poder econômico da elite industrial paulista.

As diferenças econômicas, culturais, físicas e industriais existentes entre São Paulo e Curitiba ficaram impressas nesses dois filmes que mostram cada uma das duas cidades na década de 1960 (ainda que o tempo diegético de $S \tilde{a} o \mathrm{~Pa}$ ulo $S / A$ corresponda ao período 1957-61, as filmagens aconteceram em 1965). Por mais que Back represente aspectos de Curitiba de 1968 pelo ângulo do crescimento urbano e de suas contradições, ela preserva ainda um aspecto acanhado se confrontada às imagens de industrialização e espaços culturais da monstruosa capital paulista. Mas a idéia de que os personagens têm seus próprios "lugares" dentro desses cenários da modernização aproxima os dois filmes. Assim, enquanto Carlos e Hilda passeiam entre as obras expostas - ela discorrendo sobre as particularidades que diferenciam a sensibilidade de cada artista -, a postura do rapaz indica que não é aquele o seu mundo, e nem é pela erudição artística que ele se interessa. Ele está ali somente por causa dela. E uma impressão parecida com aquela que temos ao ver Mário passeando no Country Club com Cristina, na parte final de Lance Maior, quando ele tenta formular o tão ensaiado pedido de casamento do qual a moça se desvia.

No final do filme de Back, a idéia de planificação afetiva é corroborada pela estratégia de justapor - ou de alternar, pela montagem, sugerindo simultaneísmo - as diferentes facetas de Curitiba que indicariam os diferentes estratos sociais. Nenhum dos três jovens é revelado como figura central, todos são simplesmente postos ali, apresentados em suas realidades particulares. Enquanto Cristina mostra-se entediada entre jovens numa festinha de mansão, Mário é visto na rua, andando no escuro atrás de uma prostituta que nem lhe dá atenção. A penumbra sinaliza o submundo, e o paredão ao fundo é opressor, achatando o espaço físico mostrado, enquanto a câmera acompanha Mário nessa estreiteza. Depois vemo-lo pechinchar os preços de programas com outras duas mulheres, o que o coloca numa situação de completa degradação. E Neusa, nesse trecho final, está às voltas com um paquerador que a persegue insistentemente pelas ruas oferecendo carona.

Nas frações do filme em que acompanhamos Neusa dentro do carro do paquerador, a cidade é outra vez mostrada pela câmera. Na primeira vez em que ela aceita a carona, por exemplo, vemos o centro da cidade de dentro do carro em movimento, passando pelas imediações da praça Generoso Marques. O paquerador diz: "Que carona difícil, essa...”. E Neusa: “É a primeira vez que entro no carro de um desconhecido". Em seguida, outros planos mostram vistas de dentro do 
automóvel, com a câmera situada no banco traseiro, como se fosse um passageiro invisível. Enquanto registra o diálogo travado entre o casal, exibe também o percurso que fazem, passando pelos prédios, outdoors, transeuntes e ciclistas.

Em todas as situações descritas, quando a cidade é personagem, as imagens importam tanto ou mais do que os diálogos travados. E isso acontece, também, nas cenas que contrapõem o arcaico e o obsoleto à ideia pregnante de modernidade que envolvia Curitiba na década de 1960. Não me refiro, agora, às imagens da precariedade já mencionadas, mas a outras tantas que remetem ao arcaico, ao envelhecido, se comparado às superfícies polidas das vitrinas, dos automóveis e das construções modernas.

Uma situação que contrapõe as imagens da modernização à ideia de obsolescência é a cena no interior do trem em que Mário e Neusa se conhecem. Isso ocorre logo após a exposição dos créditos do filme sobrepostos às cenas do centro de Curitiba, antes descritas. O trem, que desde o século XIX simbolizava o triunfo do homem pela tecnologia, representando o poder e a velocidade da nova era industrial, paradoxalmente aparece no filme como a imagem do obsoleto.

Os contextos histórico e diegético de Lance Maior dizem respeito a um momento da história brasileira no qual se expandia a indústria automobilística (com a entrada de várias multinacionais no país) e se ampliavam as redes viárias, difundindo-se o hábito de viajar de automóvel. ${ }^{11}$ Em Curitiba, o planejamento urbanístico já privilegiava o automóvel individual desde os anos 1940, em prejuízo do transporte coletivo, indicando a adesão ao discurso do conforto individual que acompanha o processo de modernização (Oliveira, 2000). O trem passava a ser visto como "antigo", ultrapassado e, como meio de transporte, reservado às classes menos favorecidas.

A sequência no interior do trem atua, também, como o ponto inicial da narrativa, uma vez que as cenas anteriores se destinavam a apresentar o perfil dos personagens, na seguinte ordem: Cristina, Neusa, Mário e a cidade de Curitiba. Mas quando os últimos acordes da música de Carlos Castilho mesclam-se ao ruído do trem, a imagem mostra o interior de um vagão. Um plano em perspectiva mostra toda a sua extensão interna. Os passageiros apresentam expressão aborrecida. Uns olham pela janela, outros cochilam. São pessoas comuns, de classe média baixa, que usam o trem como meio de transporte e não como curiosidade turística. Por isso, entediam-se com o tempo gasto no trajeto da viagem.

Mais ou menos no meio do enquadramento, vê-se Neusa, cabisbaixa, afundada na leitura de uma revista. Um corte nos fornece um plano médio da mesma personagem. Ao seu lado, uma mulher, talvez sua mãe, lhe pede que feche a janela, mas Neusa nem sequer ouve, absorta que está.

O plano seguinte mostra Mário, em pé num outro vagão, procurando lugar para se sentar. Assim que ele atravessa uma porta, vemos Mário de frente, 
entrando no vagão em que está Neusa. Seus olhos se fixam na moça. Num jogo de campo-contra-campo, vê-se alternadamente o rosto de Neusa, mergulhada na fotonovela, e Mário, que olha fixamente na direção em que se presume estar a moça. $\mathrm{O}$ jogo continua por alguns instantes, com Neusa percebendo-se observada por Mário, e depois lhe correspondendo aos olhares. Logo em seguida os dois aparecem conversando na parte externa do vagão. Os planos longos, as oscilações da câmera estacionada diante dos personagens, a passagem dentro do túnel, tudo concorre para criar a impressão de lentidão, associada à monotonia da paisagem que se distorce diante de nossos olhos com o movimento contínuo do trem.

FIGURA 9: Mário e Neusa no interior do trem

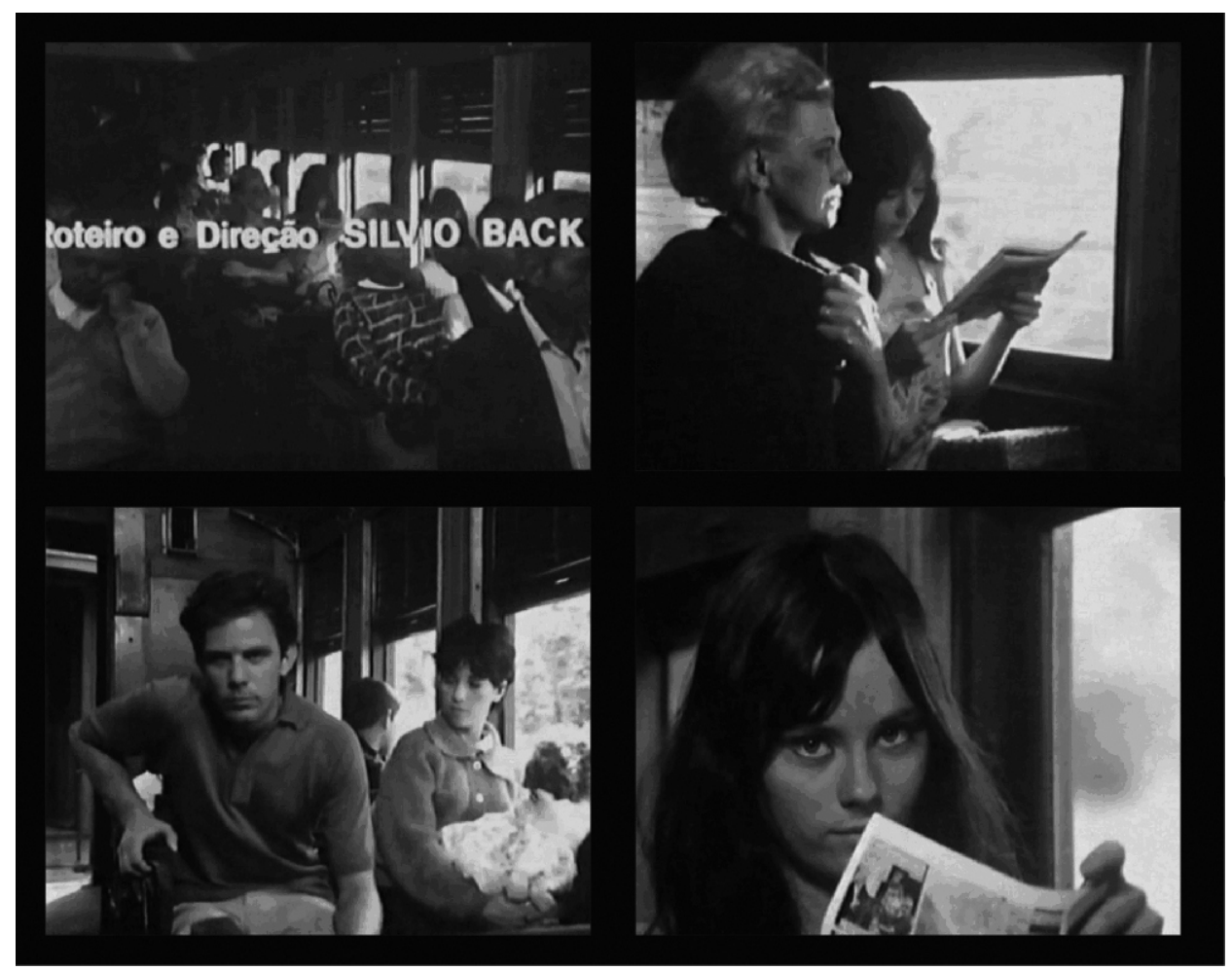

A certa altura, ao falar da pureza do ambiente rural, Neusa age como se sua ida de trem até Antonina representasse um alívio ante a rotina e o ambiente sufocante da cidade, e diz: "Como isso aqui é bom... o ar é tão puro... se desse eu morava num lugar assim". Mário divaga, charlatão: "Ah... no verão tudo isso é tão lindo! As flores...” 
Essa breve associação entre espaço rural e lugar paradisíaco evoca o clichê de que o habitante da cidade busca a pureza do campo e da natureza para compensar o confinamento urbano. Mas essas declarações dos dois tomarão um ar "forçado", conforme o filme for mostrando que suas ambições estão muito mais voltadas para os padrões de vida urbana do que para a vida simples no campo. Nesse sentido, as imagens seguintes à cena do trem mostram o marasmo na velha cidade de Antonina: a rua sem automóveis, tomada por capim, as paredes manchadas de uma construção em ruínas, o silêncio impaciente no interior da igreja vazia, a feira de rua pacata com suas pencas de bananas, as mulheres lavando baldes numa torneira pública e o menino vendendo caranguejos, à espera dos raros fregueses.

$\mathrm{O}$ arcaísmo transborda ainda da longa sequência que descreve visualmente a estadia de Neusa e Mário em Antonina. É também uma cidade-personagem, mas secundária, pois uma de suas funções é evidenciar o contraste entre o meio remoto do qual se origina Mário e a imponência da jovem capital do estado. Em todos os casos, o cenário de Antonina cria, ainda, uma atmosfera romântica para o início do namoro entre os dois jovens, que estão distantes de suas rotinas e vivem momentos idílicos. Isso corresponde, aliás, aos clichês de fotonovelas consumidas vorazmente por Neusa, que vê no início desse namoro uma possibilidade de trazer tais clichês de consumo para a vida real.

Numa parte mais avançada do filme, quando Mário vai outra vez a Antonina para ver o pai doente, o clima é mais abatido, pois não existe romance. A situação de abandono do pai de Mário sinaliza a decadência da cidade litorânea. Desde aquela apresentação de fotografias da infância de Mário no início do filme, quando a voz off do pai o aconselhava a estudar para "subir na vida", já era evidente que o velho projetava suas expectativas num suposto futuro melhor que o filho poderia conquistar na cidade grande. Mas Back, após conceder a Mário e também à Neusa o sopro de uma ambição aceitável dentro da sociedade capitalista - onde cada um procura galgar novos espaços -, não lhes concede a oportunidade de concretização de nenhum dos seus projetos. Ao término do filme, deixa aos personagens (e, por extensão, ao espectador) apenas o gosto azedo do fracasso.

\section{Conclusões}

Desde que a voz de Marília Pêra entoara a música de Carlos Castilho na abertura do filme, já estávamos avisados sobre onde tudo iria acabar: num beco sem saída. Ainda que os 20 minutos iniciais de Lance Maior surgissem promisso- 
res de romance e empenho nos projetos pessoais de cada personagem, aos poucos essas promessas se vão se mostrando evasivas. Até mesmo o ritmo com que a trama é narrada - conduzida quase todo o tempo por planos longos, alguns períodos de silêncio e poucas inserções musicais - evoca vagar no desdobramento das situações, deixando-nos apenas na expectativa de que se resolvam. Ao invés de um desfecho, há uma sucessão de momentos em que os projetos que pareciam servir de eixo narrativo ao filme são gradualmente malogrados. Todas as possibilidades que se abriram na parte inicial acabam se defrontando com a "impossibilidade" de efetivação. Isso impregna, ainda mais, as imagens curitibanas de uma melancolia urbana, de uma sensação de impotência. A ausência de projetos coletivos e de afeto verdadeiro nas relações entre os três jovens aumenta a impressão de solidão e atomização. E resta a cidade como anteparo para tantas outras experiências iguais às deles.

Como foi dito, a temática urbana marcou várias produções fílmicas no Brasil de meados ao final dos anos 1960 . O marasmo, a apatia, a falta de perspectivas e as frustrações da classe média foram tomados, mais de uma vez, para a ambientação de filmes com olhar mais crítico. Em 1966, Bernardet (1978: 89) escrevia que "o cinema que trata da classe média urbana é um cinema dos dias atuais. Existem por enquanto poucos filmes, mas já vêm se delineando algumas tendências", e situava o São Paulo $S / A$ como "o primeiro e por ora único filme crítico sobre esse tema". Ele também comentava o tratamento dos personagens representativos da classe média urbana em filmes como São Paulo $S / A$ e $O D e-$ safio (Saraceni, 1965), dizendo que neles se abria uma perspectiva fecunda: "trata-se de um corpo a corpo com a situação da classe média, não apenas de manifestar a falta de perspectiva, as contradições e hesitações, sua dependência em relação à burguesia, como também apontar precisamente como se manifesta tal situação e o que a motiva" (Bernardet, 1978: 156). Duas décadas depois, num texto que se propunha ser um balanço do cinema produzido no Brasil durante os anos de ditadura, Ismail Xavier (2001: 63) também mencionou a presença, no final dos anos 1960, de "filmes preocupados com a passividade política do povo". E é nessa linha mais crítica do cinema urbano produzido no Brasil na década de 1960, e que se pode dizer ter sido iniciada na década de 1950 por Nelson Pereira dos Santos e Roberto Santos, que visualizo Back se inserindo com o Lance Maior, em plena euforia progressista vinculada às políticas de modernização de Curitiba. 
1. A versão final do roteiro de Lance Maior foi elaborada por Sylvio Back em parceria com os jornalistas Oscar Milton Volpini e Nelson Padrella.

2. Uma análise minuciosa sobre os significados históricos dessa apresentação de cada personagem no prólogo do filme já foi publicada por mim em forma de artigo. Ver Kaminski, 2006: 209-216.

3. Segundo Magalhães (2001:64), “a conjuntura que se apresenta no Paraná nas décadas de 1950-60 subordina-se ao modelo político adotado pelo governo central, conhecido como "era desenvolvimentista". A formulação de uma política econômica e social de modernização do Paraná remonta a Manoel Ribas (governador e interventor durante o Estado Novo), de quem Moysés Lupion foi considerado "herdeiro" desde que foi eleito governador pela primeira vez, em 1947, pelo Partido Social Democrático. A política de modernização do Estado foi retomada na sua segunda gestão (1956-1961), dando sequência à "onda de prosperidade" que marcou a década. Ver Kaminski, 2006: 55-65.

4. "No Paraná [...] as economias proporcionadas pela alta produtividade do setor agrícola (café) serão aproveitadas dentro do território estadual quando o Governo estabelecer o clima favorável à industrialização paranaense". Citação extraída do Programa Governamental de Desenvolvimento PGDE da PLADEP - elaborado em 1959.

5. Na gestão de Arzua o plano urbanístico de Curitiba foi revisto, e foi gestado o embrião do atual Plano Diretor da cidade de Curitiba.

6. No Brasil dos anos 1960, o governo militar investia na política de crescimento econômico-industrial, que proporcionava a expansão do consumo de bens duráveis e a elevação dos padrões de vida da classe média, garantindo a aderência dessa fatia da população aos projetos do governo. Para maiores detalhes, consultar D'Araújo e Soares (orgs) (1994) e Mendonça (1995: 68-69).

7. De acordo com Poulantzas (apud Evers, 1982: 87), a "classe média" se caracteriza, entre outros traços, pelo mito da ascensão social e a aspiração ao status burguês, pelo individualismo, pelo medo da revolução e pela inconstância política.

8. "Aqueles que não mais possuem quaisquer meios de produções e, por isso, vendem sua força de trabalho, embora fora do processo de produção material" (Evers, 1982: 87).

9. A inauguração de um parque industrial em Curitiba aconteceu apenas no começo da década de 1970, na primeira gestão do prefeito Jaime Lerner, coincidindo com a implantação do plano urbanístico que vinha sendo preparado desde a gestão de Ivo Arzua. Assim, Curitiba se tornava a expressão do "milagre brasileiro" em sua versão urbana.

10. Os clubes eram locais de lazer importantes na Curitiba de 1950-60 (Santos, 1997: 84). O Clube Duque de Caxias foi o primeiro a construir piscina em 1952. Depois outros fizeram o mesmo: o Curitibano, o Thalia, o Concórdia, o Círculo Militar e o Santa Mônica.

11. No governo Kubitschek, foram oferecidos estímulos fiscais e cambiais às empresas multinacionais interessadas na produção automobilística em solo brasileiro. Elas deveriam se comprometer com a nacionalização dos veículos fabricados (através do fornecimento de autopeças por indústrias nacionais, conforme ilustrado no filme $S \tilde{a} o$ Paulo $S / A)$. 


\section{Referências bibliográficas}

ARENDT, H. A crise na cultura: sua importância social e política. In: — Entre o passado e o futuro. São Paulo: Perspectiva, 2003.

BACK, S. Curitiba ao avesso: os subterrâneos do silêncio. Revista Panorama, Curitiba, n.117, fev. 1962.

Por que não se ama o filme brasileiro? Revista Panorama, Curitiba, n.174, jan. 1967.

Jovens sem poder. O Estado do Paraná. Curitiba, 29 set. 1968.

BAUDRILLARD, J. A sociedade de consumo. Lisboa: Edições 70, 1972.

BERNARDET, J.-C. Brasil em tempo de cinema. Rio de Janeiro: Paz e Terra, 1978.

D'ARAÚJO, M. C. e SOARES, G. (orgs). 21 anos de regime militar: balanços e perspectivas. Rio de Janeiro: FGV, 1994.

EVERS, T. Sobre o comportamento político das classes médias no Brasil, 1963-
1977. In: KRISCHKE, P. J. (org). Brasil: do "milagre" à "abertura”. São Paulo: Cortez, 1982.

KAMINSKI, R. O cinema na mídia e a mídia no cinema: o filme Lance Maior nos debates sobre os meios de massa. ArtCultura, Uberlândia, v.8, n.13, jul-dez. 2006, p. 203223.

MAGALHÃES, M. B. Paraná: política e governo. Curitiba: SEED, 2001.

MENDONÇA, S. A industrialização brasileira. São Paulo: Moderna, 1995.

OLIVEIRA, D. Curitiba e o mito da cidade modelo. Curitiba: Ed. UFPR, 2000.

SANTOS, A. Cesar. Memórias e cidade. Curitiba: Aos Quatro Ventos, 1997.

VOLPINI, O. Milton. Curitiba crítica. $O$ Estado do Paraná. Curitiba, 29 set. 1968.

XAVIER, I. O cinema brasileiro moderno. São Paulo: Paz e Terra, 2001.

\section{Resumo}

Este texto analisa imagens de Curitiba enquanto personagem do filme Lance Maior, de Sylvio Back (1968). O objetivo é refletir sobre as contradições sociais que acompanharam o processo de modernização urbana naquela cidade nos anos 1960, conforme evocadas pelo filme. Além da análise reflexiva de trechos do filme, em alguns momentos são cotejadas as formas usadas por Person no filme São Paulo S/A (1965) e por Back para representar a paisagem da cidade moderna. Assim, pondera-se sobre o lugar de Lance Maior no cenário do cinema brasileiro dos anos 1960, visto que a representação dos dilemas urbanos perpassa diversos filmes feitos naquela década. Palavras-chave: Curitiba; anos 1960; cinema; Sylvio Back; modernização urbana. 


\section{Abstract}

This article analyzes the images of Curitiba as a character of the movie picture Lance Maior, by Sylvio Back (1968). The aim is to think about the social contradictions that accompanied the urban modernization in this city in the 1960s, as evoked in the film. It analyzes parts of the film and compares the methods used by Person in São Paulo S/A (1965) and Back to represent the landscape of the modern city. Lance Maior is situated in the scenario of Brazilian cinema of the 1960s, among other films of the decade that represent urban dilemmas.

Key words: Curitiba; the 1960s; cinema; Sylvio Back; urban modernization.

\section{Résumé}

Cet article analyse les images de Curitiba en tant que personnage du film Lance Maior, de Sylvio Back (1968). Le but est de réfléchir sur les contradictions sociales qui ont accompagné la modernisation urbaine de cette ville dans les années 1960, comme évoqué par le film.

On analyse des séquences du film et on compare les méthodes utilisées par Person dans São Paulo $S / A$ (1965) et Back pour représenter le paysage de la ville moderne. On situe finalement Lance Maior dans le cadre du cinéma brésilien des années 1960, parmi les autres films de la décennie représentant les dilemmes urbains.

Mots-clés: Curitiba; années 1960; cinema; Sylvio Back; modernisation urbaine. 